\title{
SEYYİD EBULKÂSIM NEBÂTÎ VE SÂKÎNÂMESİ
}

\section{Mehmet Nuri ÇINARCI*}

\begin{abstract}
$\ddot{\mathbf{O}} \mathbf{z}$
Klasik Türk edebiyatında önemli bir yer tutan sâkînâmeler, ilk olarak İran edebiyatında ortaya çıkmıştır. Türk edebiyatında ilk örnekleri XIV. yüzyıldan itibaren verilmeye başlanan sâkînâmeler, XX. yüzyıla kadar aralıksız bir şekilde kaleme alınmıştır. Çoğunlukla şairlerin divanlarında kaside, mesnevi ve terkib-i bend gibi nazım şekilleriyle yazılmalarına rağmen bazen de başlı başına müstakil birer kitap olarak yazıldıkları da olmuştur. Bezm, saki ve mey üçgeninde cereyan eden olayları aktaran bu tür, içki ve içki meclisleriyle ilgili birçok duygu, düşünce ve kavramı kimi zaman tasavvufi kimi zaman da dünyevi bir algıyla aktarır. Klasik edebiyatımızda sâkînâmeler ile ilgili yapılan çalışmaların önemli bir çoğunluğu Osmanlı sahasında verilen örneklere dayalıdır. İran'da yazılmış sâkînâmeler üzerinde yapılan çalışmalarda ise bahis konusu numuneler sadece Farsça yazılanlarla sinırlandırılmıştır. Seyyid Ebulkâsım Nebâtî, XIX. yüzyılda bugünkü Güney Azerbaycan topraklarını da içeren İran'da yaşamıştır. Ancak Fars dilinin merkezi olan bir bölgede yaşamasına rağmen Sâkînâme'sini Türkçe yazmayı tercih etmiştir. Kaçarlar dönemi İran'ında yaşayan Nebâtî, içerisinde Farsça ve Türkçe şiirlerin yer aldığı divan sahibi bir şairdir. Azerbaycan ve İran'ın muhtelif kütüphanelerinde divan nüshaları bulunan şairin Sâkînâme'si divanında mevcuttur. Bu çalışmamızda bir yandan şairin hayatıyla ilgili bilgi verilirken diğer yandan Bakü El Yazmaları Enstitüsü ve Tahran İslami Şura Kütüphanesi'ndeki divanda yer alan Sâkînâme'nin karşılaştırmalı metni yapılmıştır.
\end{abstract}

Anahtar Sözcükler: Seyyid Ebulkasım Nebâtî, Sâkînâme, terci-i bend, Azeri Edebiyati.

\section{SEYYID EBULKASIM NEBATI AND HIS SAKINAME}

\begin{abstract}
Classical Turkish literature an important place in the righteous studies have emerged in Iranian literature. The first examples of Turkish literature XIV. from start to be cautious studies century XX. It has been an unbroken century until the pen. Mostly ode the poet of the court, though written with mesnevi and terci'-i bend like they were written as prose sometimes become detached in a book in itself. Bezm such incidents occurring in the transfer saki and vege triangle, drink and drink a lot of emotions about the council, sometimes mystical thought and the concept is sometimes a perception conveyed by the mundane. A significant majority of studies on classical literature and our cautious business strategy is based on the examples given in the Ottoman court. In studies on studies written cautious in Iran Persian theme samples it is limited only to those articles. Sayyid Ebulkâsım Nebati my vegetable XIX. South Azerbaijani land including the current century has lived in Iran. However, despite living in a region which has chosen to leave the center of the Persian language Turkish the Sâkînâme. They live in the Qajar era vegetable Iran, in Persian and Turkish poetry with a sofa where the
\end{abstract}

\footnotetext{
* Yrd. Doç. Dr.; Yüzüncü Y1l Üniversitesi, Eğitim Fakültesi, Türk Dili ve Edebiyatı Eğitimi Bölümü, mehmetnuriedb@gmail.com.
} 
poet. Azerbaijan and the Iranian poet who sofas copies are available at various libraries Sâkînâme sofa. Baku Manuscripts İnstitute about this study with one hand while the other hand, the poet's life and Tehran Institute of Manuscripts of the Islamic Shura council Sâkînâme located in the Library were compared for text.

Keywords: Seyyid Ebulkasım Nebati, Sakiname, terci-i bend, Literary of Azeri.

\section{Giriş}

İran ve Arap edebiyatı menşeli bir tür olan sâkînâmeler ${ }^{1}$, esas itibariyle hamriyyat olarak adlandırılan ve muhteva bakımından şarabı anlatan şiirlerden türemiştir. Özellikle İslamiyet öncesi İran'da hüküm süren Sasani saraylarında aşk ve şarabı anlatan şiirlerin yazıldığı görülmektedir. Sasanilerden önce dahi Pişdadiyan hanedanına mensup İran hükümdarlarından Cemşid'in şarabın mucidi olarak kaynaklarda geçmesi bu savı güçlendirmektedir. İslamiyet'in İran bölgesine yayılmasından sonra şekillenen yeni Farsça ile şiir yazan ilk şairlerin örnek aldığı Arapça manzumelerde önemli bir yer tutan şarap konulu şiirler Farsça şiirde de belirli bir yere sahip olmuştur (Karaismailoğlu, 2013, s. 14). Fakat zamanla İslam medeniyeti dairesine giren Acemler, İslam dininin şarabı yasaklayıcı hükümleri karşısında duraklamışlar ve dinî endişelerle bir süre şarapla ilgili manzumeler yazmamışlardır (Canım, 1998, s. 25). Gaznelilerden itibaren kaleme alınan sâkînâmeler Farsça yazılmış ve özellikle Rûdeki, Ömer Hayyâm, Nizâmî, Selmân-1 Saveci ve Hafız gibi büyük şairlerin elinde işlenerek önemli bir gelişme kaydetmiştir. Ancak bahsi geçen şairler içerisinde sâkînâmenin bir tür olarak hüviyet kazanmasında Nizâmî’nin müstesna bir yeri vardır. Nizâmî’yle birlikte sâkinâmelerin genel çerçevesi çizilmiş ve kendisinden sonraki Fars edebiyatında yazılmış sâkînâmelere kaynaklık etmiştir.

Sâkînâmeler, Fars edebiyatında ortaya çıkmasına rağmen Türk edebiyatında daha büyük bir ilgi görmüş ve Osmanlı Devleti’nin kuruluşundan yıkılışına kadar hemen hemen her yüzyılda hemen her nazım şekliyle örnekler vermiştir. Türk edebiyatındaki ilk sâkînâme örneği Anadolu sahası dışında verilmiştir. Harezmî'nin Mahabbetnâme adlı eserinin içerisinde sakiye seslenmelerden teşekkül birkaç beyit, edebiyatımızdaki ilk sâkînâme örneği olarak bilinmektedir. Harezmî’den sonra şiirlerini Çağatay Türkçesiyle yazan büyük şair Ali Şîr

\footnotetext{
${ }^{1}$ Sâkînâmeler ile ilgili detaylı bilgi için bkz. Arslan, Mehmet (2003) Aynî, Sâkînāme, İstanbul: Kitabevi Yayınlar, Canım, Rıdvan (1998) Türk Edebiyatında Sâkînâmeler ve İşretnâme, Ankara: Akçağ Yayınları, Karaismailoğlu, Adnan (2013) "Fars Edebiyatında Sâkînâmeler," Türkiye Diyanet Vakfi Íslam Ansiklopedisi, Türkiye Diyanet Vakfi Yayınları C. 36, s. 14-15, İstanbul, Kortantamer, Tunca (1983) "Sâkînâmlerin Ortaya Çıkışı ve Gelişimine Genel Bir Bakış," Türk Dili ve Edebiyatı Araştırmaları Dergisi II (Prof. Dr. Harun Tolasa Özel Sayısı), İzmir: Ege Üniversitesi Yayınları, s. 117-123,
} 
Nevâyî ile birlikte türün devamı sürmüştür. Sâkînâme, Nevâyî'nin Fevâidü'l-kiber adını taşıyan divanındaki sâkinâme olup bazı nüshalarda adı "Mesnevi" olarak geçemektedir (Levent, 1966, s. 197-210). Anadolu sahasında yazılan ilk sâkînâme ise Ahmed-i Dâî'nin yedişer bend hâlinde kaleme aldığı terci-i bendidir. Eser Emir Süleyman için yazılmıştır. Hem uslubu hem de kendisi için yazıldığı kişi, bu bağımsız küçük sâkînâmenin tasavvufi değil, tamamen dünyevi olduğunu göstermeye yeterlidir (Kortantamer, 1983, s. 83-84). Türk edebiyatında sâkînâme türünün ilk orijinal örneği; Edirneli Revânî (öl. 1524)'nin İşretnâme adlı eseridir (Canım, 1998, s. 43). Yavuz Sultan Selim'e takdim edilmek için yazılan İşretnâme, aynı zamanda klasik edebiyatta sâkînâme türünde yazılmış ilk müstakil eserdir. Revânî’den sonra Anadolu sahasında yazılan sâkînâmeler, varlıklarını hem nitelik hem de nicelik bakımından geliştirerek devam ettirmiştir. Sâkînameler her yüzyılda devrin önemli şairleri tarafından ya divanlarında yer verilmiş ya da müstakil bir eser olarak yazılmışlardır. XVI. yüzyılda Fuzûlî, Hayretî, Taşlıcalı Yahyâ, XVII. yüzyılda Nef'i, Nev'izâde Atâyî, Şeyhülislâm Yahyâ, XVIII. yüzyılda Nevres-i Kadîm, Şeyh Gâlip ve XIX. yüzyılda Keçecizâde İzzet Mollâ ve Hoca Neş'et gibi şairlerin sâkinâmeleri meşhurdur.

Sâkînâmeler genel itibariyle içki ve içkiye ait unsurlardan saki, bezm, mutrib, kadeh ve mahbub gibi bazen uzak bazen de yakın kimi ifadelerin şiirle anlatımı esasına dayanan bir türdür. Asırlar boyunca sâkînâmeler, dünyanın varlığı, onun gelip geçiciliğii, biz insanoğlunun bu geçici ve yok olucu neşe içerisindeki acılı sonu, bu yalancı varlığın ruhumuzun üzerine koyduğu minnet yükünün dertlerinden ve kederlerinden kurtulmak için sarhoşluk ve idraksizlik âlemine sığınma, dünya harabesinden harabatın aydınlık yoluna kaçış, kaybolan arzuları şarapçının mahallesinde yani meyhânede aramak ve bulmak, pîr-i mugânın peykesinde yani dergâhında hakkın ve hakîkatın cilvesini seyretmek için en elverişli saha idi (Canım, 2010, s. 207). Sâkînâmelerde kullanılan bu kavramlar asıl anlamlarıyla kullanıldıklarında şairin eserini dünyevi bir algıyla yazdığı anlaşılır. Ancak bazı şairlerin yine aynı kavramları kullandıkları hâlde esas amaçlarının dünya zevklerinden vazgeçmeyi öğütleyen tasavvufi bir gaye taşıdığı görülür. Tasavvufu anlatmak için yazılan sâkinâmelerde içki ve içki meclislerine özgü kavramların kulanımı genellikle semboliktir. Bu tarz sâkînâmelerde şarap, ilahi aşkı, sarhoşluk ise vecd hâlini ifade eder. Mürit, Allah aşkı olan bu şarabı içer ve kendinden geçerek dünyevi sıkıntılarından kurtulur. İlahi aşkın nûş edildiği meyhâne tekke, ilahi aşkı meyhânede müritlere sunan pîr-i mugan ise tekkenin mürşid-i kâmilidir. Bunun dışında sâkînâmelerde "şarabın bulunuşu, şarabın faydası ve zararları, şarabın çeşitleri ve kullanılışı, kadehin çeşitleri, 
meyhanenin ve meclisin özellikleri, pîr-i mugânın özellikleri, mevsimler, gündüz ve gece, mehtap, dişarda şarap içilecek mekânlar, musiki aletleri, mum vb." birçok konu eserlerin özelliğine göre birkaç beyitle veya ayrıntılı olarak işlenmiştir (Arslan, 2003, s. 16).

Sâkînâmeler, müstakil birer eser olarak yazllabildikleri gibi şairlerin divanlarında mesnevi, kaside, terkib-i bend ve terci'-i bend şeklinde çeşitli nazım şekilleriyle de kaleme alınmışlardır. Ayrıca bazı mesnevilerde ara sıra bölüm başlarında ve sonlarında dağınık olarak "sâkînâme" başlığı altında iki beyitlik küçük bir bağlantı ile sakiye seslenildiği de görülmektedir (Canım, 1998. s, 12). Hem İran hem de Türk edebiyatında genellikle sâkînâmeler aruz vezninin mütekârib bahrinin Fa'ûlün, Fa'ûlün, Fa'ûlün, Fa'ûl veya dört Fa'ûlün kalıbıyla yazılmışlardır. Bununla birlikte aruzun farklı kalıplarıyla yazılan sâkînâmeler de olmuştur.

\section{Seyyid Ebulkâsım Nebâtî’nin Hayatı}

XIX. yüzyıl Azeri edebiyatı şairlerinden olan Seyyid Ebulkâsım Nebâtî, bugün İran sınırları içerisinde yer alan Karacadağ şehrine bağlı Üştübin adındaki bir köyde doğmuştur. Şairin doğum tarihi ile ilgili kaynaklarda farklı bilgiler yer almaktadır. Feridun Bey Köçerli Azerbaycan Edebiyatı Tarihi adlı kitabında net bir bilgi vermeden şairin Hicri XIII. yüzyılın başlarında doğduğunu belirtmektedir (Köçerli, 1920, s. 531). Aziz Devletabadi, Sühanverân-ı Âzerbaycan eserinde şairin doğum tarihinin Hicri 1191 (1778) olduğunu ifade etmektedir. Şairin Türkçe ve Farsça şiirlerini İran'da yayımlayan Hüseyin Muhammedzade Sadık ise Nebâtî'nin doğum tarihini Hicri 1179 (1766) olarak vermektedir. Seyyid-i muhterem Muhammed Üştübinli'nin oğlu olan Seyyid Ebulkâsım, şiirlerinde Nebâtî mahlasının yanı sıra kimi zaman Mecnûnşâh kimi zaman da Hânçobanî mahlaslarını kullanmıştır (Terbiyet, 1390, s. 546). Çocukluk yıllarını Karacadağ'da bağcılık ve hayvancılıkla geçiren Nebâtî, gençliğinde Ahar'a gelmiş ve Şeyh Şihabeddin dergâhında bir süre riyazetle meşgul olmuştur (Tebrizi, 1347, s. 129). Fikri açıdan ömrünün ilk yıllarında sufiliğe meyletmiş sonrasında ise Şiiliğe yönelmiş ve bunun etkisiyle Hazreti Ali’ye kasideler yazmış sufi bir Şii'dir. Ömrünün son yıllarında doğum yeri olan Üştübin'e dönmüştür. Nebâtî'nin doğum tarihi ile ilgili ihtilafa düşen kaynakların önemli bir çoğunluğu, ölüm tarihi konusunda hemfikirdirler. Muhammed Ali Terbiyet, Muhammed Deyhim, Müderris Tebrizi ve Sadık Muhammedzade, eserlerinde şairin ölüm tarihi olarak Hicri 1262 (1846) tarihini verirler. Sadece Feridun Bey Köçerli kesin olmayan rivayetlerden hareketle Hicri 1273 (1857) olabileceğini ifade eder. Kabri doğduğu yer olan Üştübin'dedir. 
Kaynaklarda Nebâtî’nin ismiyle birlikte kullanılan seyyit ibaresi, onun Hazreti Peygamber soyundan geldiği ihtimalini güçlendirmektedir. Onun aslı, kadim devirlerden beri Arabistan'da, İran'da ve Azerbaycan'da geniş bir alana yayılmış Nebâtîler tayfasındandır (Hüseyni, 2004, s. 4). Babası Mir Yahya Muhammed, bulunduğu toplumdaki bireylere İslami akideleri ve tasavvuf adabını telkin etmiş önemli şahsiyetlerden biridir. İlk eğitimini babasının yanında alan Nebâtî, Güney Azerbaycan'ın birçok şehrini ziyaret etmiştir. Şiirlerinden anlaşıldığı kadarıyla doğmuş olduğu Karacadağ dışında Karabağ, Lenkeran, Salyan, Ağdam, Erdebil gibi şehirlerde de bulunmuştur (Sadık, 1385, s. 48). Nebâtî, babasından öğrendiği tasavvufi kaidelerle dervişane bir yaşantı sürmüş ve etrafında topladığı müritler arasında nüfus sahibi olmuştur. Öte yandan Ahar'ı ziyareti esnasında Şeyh Mahmud Şihabeddin'in makberini ziyaret ettikten sonra dünya işlerinden el etek çekerek inzivaya çekilmiştir. Bu inzivanın temel gayesi ise kendisinin de şiirinde ifade ettiği gibi hakikat âleminin gizli sırlarına vakıf olmaktır.

Gûşe-i vahdet ne 'aceb câ imiş

Sırr-ı nihân onda hüveydâ imiş (Hüseyni, 2004, s. 5)

Nebâtî, derviş kimliğinin yanısıra Nimetullahi tarikatının da müritlerindendir. Nimetullahi tarikatı, Seyyid Nimetullah Veli’nin ölümünden sonra taraftarları tarafindan Kirman bölgesinde kurulmuştur. Nebâtî'nin yaşadığı dönemde Nimetullahilerin kutbu Muhammed Cafer Hemedânî’dir. Hemedânî’nin ölümünden sonra Nimetullahi tarikatı iki kol hâlinde gelişimini sürdürmüştür. Bunlardan ilk kolun şeyhi Hacı Zeynelabidin Merâĝî, ikinci kolun şeyhi ise Erdebîlî Nâsır Şâh’tır. Bugün Tebriz'de yaşayan Nimetullahilerin inancına göre Nebâtî, Nâsır Şâh'ı görmek için Erdebil'e gitmiş ve orada ona iradet eli vererek onu kendisine rehber edinmiştir (Sadık, 1385, s. 51). Zaten Nebâtı̂’nin ömrünün son yıllarında fikrî yönüyle tasavvufi dünya algısından Şii ağırlıklı bir düşünce tarzını benimsemesinin en önemli sebebi, Nimetullahi tarikatının etkisidir. Divanında yer alan şiirlerin önemli bir kısmında bu tarikatın çeşitli iz düşümlerine rastlamak mümkündür. Şairin aşağıda yer alan Farsça beyitleri hem Nimetullahi hem de Şii mezhebinin tesirini görmek açısından önemlidir:

Çend porsî tu tarikat-ı mâ

Kuçek-i abdâl-ı şâh-ı Mâhânîm

Tâlib-i şâh Ni'metu'llahîm 
Seg-i kûy-i 'Aliyy Imrânîm² (Sadık, 1385, s. 52)

Meşhûr ü şehîd ü şâhid ü şah-ı cihân

Şek nîst ki şah Ni'metu'llah 'Alî-est ' (Sadık, 1385, s. 52)

Kaynakların ortak kanaatine göre Nebâtî, riyazet ehli olduğundan zamanının önemli bir kısmını insanlardan ayrı itikaf içinde geçirirmiş. İtikaf dışındaki zamanında ise dışarı çıkar halkla sohbet edermiş. Ziyadesiyle şirin sözlü olduğundan çoğu kişi ona hayranlık duyar ve muasırlarından birçoğu onunla sohbet edebilmeyi kendileri için büyük bir iftihar vesilesi sayarlarmış (Köçerli, 1920, s. 534). Yine bu sohbetleri esnasında şevke gelen Nebâtî, aşk, şarap ve sevgiye dair doğaçlama şiirler okurmuş. Nebâtî, daha önce de ifade edildiği gibi bağcılık ve hayvancılıkla uğraşmıştır. Şiirlerinde de Hançoban ve Hançobani mahlaslarını kullanan Nebâtî’nin büyük bir ihtimalle çobanlık yaptığı âşikardır. Nitekim Ebulfazl Hüseyni aşağıdaki şiirinden hareketle onun mutlak surette çobanlık yaptığını öne sürer:

Koyunu yüz eyledüm bu çölde klşlak etmenem

Ziynet-i mülk-i Muğan Ultanı gözler gözlerim (Hüseyni, 2004, s. 100)

Nebâtî’ye ait kaynaklarda belirtilen tek eseri Türkçe ve Farsça şiirlerinin yer aldığ1 Divan'ıdır. Öte yandan Muhammed Deyhim Tezkire-i Şu'arâ-yı Âzerbaycan adlı eserinde şaire ait Ayne'l- 'aşk adlı manzum bir eserin varlığından bahsederek bu eserin Lahor'da basıldığını söylemektedir. Deyhim yine aynı eserinde Nebâtı̂’ye ait divan nüshalarından birer adetlerinin İslami Şura Kütüphanesi, Tahran Üniversitesi Merkez Kütüphanesi ve Tebriz Millî Kütüphanesi'nde olduğunu belirtmektedir (Deyhim, 1986, s. 241). Bununla birlikte Nebâtî’ye ait bir divan nüshası da Bakü El Yazmaları Enstitüsü’nde B-651/11152 kayıtlı numarada yer almaktadır. Nebâtî'nin divanı ilk olarak Hicri 1284 (1868) tarihinde taş basma olarak Tebriz'de basılmıştır. Şairin hem Farsça hem de Türkçe şiirleri Sadık Muhammedzâde Hüseyin tarafından Tebriz'de basılmıştır. Nebâtî’nin divanı nazım şekilleri bakımından bayağı zengin bir içeriğe sahiptir. Divan içerisinde kasideler, gazeller, müstezatlar, muhammesler, rubailer, tek-beytler, dü-beytler, mesnevi, müseddes, bahr-1 tavil ve mülemma vardır. Nebâtî de Osmanlı sahası klasik şairleri gibi divan edebiyatı nazım şekillerinin yanı sıra halk edebiyatı nazım şekilleriyle

\footnotetext{
${ }^{2}$ Bana birkaç kez tarikatımı sordun. Ben Mâhân şahının küçük abdalıyım. Şah Nimetullah'ın takibçisi, Hazreti Ali'nin köyünün köpeğiyim.

${ }^{3}$ Cihanın şahı, şahidi, şehidi ve meşhuru şüphesiz Nimetullah ve Ali'dir.
} 
de şiirler yazmıştır. Nitekim divanında tecnisler, geraylılar ve koşmaların yer alması bunun en büyük delilidir.

Nebâtî, dervişane yaşam tarzı ve tasavvufi düşüncenin şekillendirdiği hayat algısı neticesinde doğal olarak şiirlerinde de tasavvuf öğretisini işlemiştir. Zamanının önemli bir kısmını ibadetle geçiren Hakperest bir şair olduğundan şiirlerinin mühim bir bölümünde bu münzevi hayatın ruhunda uyandırdığı dinginliği görmek mümkündür. Hayat karşısındaki dindar tutumu, insanları da bu yola davet etmeyi gerektiren şiirlerinin ortaya çıkmasına zemin hazırlamıştır. Özellikle Nimetullahi tarikatına bağlanması neticesinde Şii mezhebine olan ilgisi giderek artmış ve sonrasında şiirlerindeki Hazreti Ali sevgisi aleni bir şekilde ortaya çıkmıştır. Nebâtî, Hazreti Ali'nin hakiki ve samimi meddahlarından olduğu için o cenabın vasfını öven çok güzel kasideler yazmıştır (Köçerli, 1920, s. 536). İranlı şair Hafız'ın şiirlerini tedkik eden Nebâtî, aynı zamanda Mevlânâ ve Hayyâm'ı da okumuştur. Hatta Sâkînâme'sinde Hafız'a olan hayranlığını dile getirmekten imtina etmez:

\section{Hâfiz'ın rûh-ı pâkine bizden}

Bir yitür 'aşk-ı bî-şümâr gine (2. Bend, 20)

Nebâtî, bugün dahi İran topraklarında yaşayan Azeri Türkleri için seçkin bir şahsiyet ve çoğu insanın şiirlerini ezbere bildiği önemli bir Türk şairidir. Seyyid Ebulkasım Nebâtî’nin şair olarak yaşadığ 1 coğrafyadaki Azeri Türkleri için önemini Feridun Bey Köçerli şu cümlelerle çok güzel bir şekilde ifade etmiştir: "Seyyid Ebulkâsım Âzerbaycan Türklerinin Hâce Şemseddîn Hâfiz'l ve Şems-i Tebrîzî ve bazı makâmlarda Mevlânâ Celâleddîn-i Rûmî'si menzîlesindedir. Nice ki Hâfiz fesâhat ve belâgatde şu'arâ-yı Fârs'in ser-defteri olup hemçünin Nebâtî de Âzerbaycan şu'arâsının fasîhrâkidir." (Köçerli, 1920, s. 544).

\section{Seyyid Ebulkâsım Nebâtî’nin Sâkînâmesi}

Türk edebiyatında yer alan sâkînâmeler, bazen müstakil birer eser olarak kaleme alındıkları gibi çoğu zaman da şairlerin divanlarında mesnevi, kaside, terkib-i bent ve terci-i bent gibi nazım şekilleriyle yazılmışlardır. Çalışmamızın konusu olan Seyyid Ebulkâsım Nebâtî'nin Sâkînâme'si de kendi divanında terci-i bent nazım şekliyle yazılmıştır. Aruzun Hafif bahrinin Fecilâtün Mefâcilün Fecilün (Fâcilâtün Mefầcilün Faclün) kalıbıyla yazılan Sâkînâme, 12 bent ve 329 beyitten oluşmaktadır. Sâkînâme, Nebâtî divanının İslami Şura Kütüphanesi’nde yer alan nüshanın 321-389 sayfaları, Bakü El Yazmaları Enstitüsü'nde yer alan nüshanın ise 6b-18b varakları arasında yer almaktadır. Her iki nüshanın da istinsah tarihleri belli değildir. Bu yüzden 
İslami Şura Kütüphanesi'nde bulunan nüsha Bakü nüshasına göre eksiksiz olduğundan ana metin olarak seçilmiştir. Karşılaştırmalı metin olarak hazırladığımız Sâkînâme metninde, nüsha farklı1ıkları dipnotlarda gösterilmiştir. Bakü nüshasına karşılık B harfi kullanılmıştır.

Nebâtî, Sâkînâme'ye Allah'ın varlığını ve birliğini öven bir tevhidle başlar. Tevhidde Allah'ın âlemi yoktan var ederek yeri, göğü, güneşi ve ayı yarattı̆̆ı, Âdem'in başına şeref (kerremnâ) tacını koyduğu, bu yüzden de her işe onun ismiyle başlanması ve bütün hamd ü senaların onun yüce zatına sunulması gerektiği vurgulanır.

\author{
Koyginen başa tâc-ı Bismillâh \\ İbtidâ kıl sözü be-nâm-ı Hudâ \\ Ki odur her kelâma ser-matla \\ Ki odur server-i heme esmâ \\ Kâdir-i zü'l-celâl ve'l-ikrâm \\ Fâlaku's-suhub hâlıku'l-eşyâ \\ Sâni'-i arş u ferş ü şems ü kamer \\ 'Âlemi yohdan eyleyen peydâ \\ Âdemi o yaratdl topră̆dan
}

Başına koydı tâc-ı kerremnâ (1. Bend, 2-10)

Türk edebiyatında yazılan sâkînâmeler, genellikle ya gerçek içki ve içki meclislerinden bahsederler ya da içki ve içki meclisine özgü kavramlara sembolik birer değer yükleyerek tasavvufi manada bir mesaj vermeye çalışırlar. Nebâtî'nin Sâkînâme'si de özellikle kendisinin Nimetullahi tarikatına mensup bir mürit olması hasebiyle tasavvufi bir nitelik taşır. Sâkînâme'nin hemen ilk bendinin ilk iki dizesinde aşk derdine düşmüş ve sevdanın elinden eziyet çeken bir âşık portresi çizilir. Şüphesiz bu aşk Allah aşkıdır.

Ey iden 'aşk nâmesin inşâ

Veh düşüp başına 'aceb sevda (1. Bend, 1)

Genel bir kompozisyon olarak değerlendirildiğinde, Sâkînâme'de işte bu hastaya nasıl bir tedavi uygulanması gerektiği ile ilgili mey, meyhane ve saki kavramları üzerinden reçete sunulur. Aşka düşmüş aşk ehlinin yapacağı ilk iş, aşk yoluna korkusuzca girmek ve zaman 
kaybetmeden işin ehli bir pirden el alarak bu cefalı yolda yürümeye başlamaktır. Pirin aşk yolundaki en büyük rehber olduğu birçok yerde tekrarlanır:

Himmet al pîrden meded Hak'dan

Dem-be-dem hû çeküp yola başla

Koy kadem râh-ı 'aşka merdâne

Gir harâbâta mest ü mestâne (1. Bend, 23-24)

Pîr-i meyhâneden gel al himmet

Diginen yâ müfettihe'l-ebvâb (3. Bend, 18)

Rencsiz râhat olmaz ey oğlan

Yüri git kulluk eyle üstada (4. Bend, 10)

Aşk derdinden eziyet çeken aşığın nasıl bir derde müptela olduğu ve bu derdin onu ne hâle soktuğu detayıyla anlatılır. Aşk derdinin aşığa çektirdiği eziyet aşığın kendi dilinden şöyle anlat1lır:

Sâkiyâ ey enîs-i cân-perver

Meni gam itdi 'aciz ü muztarr

Men gören zulmi görmesin tersâ

Men çeken derdi çekmesün kâfir

Ne tegâfüldü bu hani mînâ

Ne ta'allüldü bu getür sâgar

Vir pey-â-pey o kana dönmüşden

Üregüm yandı dutmuşam âzer

Derd idüp serv-i kaddimi çün dâl

Hicr idüp reng-i âlımı asfer (5. Bend, 1-5)

Sâkiyâ devr getür mey-i gülgûn

Meni gam itdi lâle tek dil-hûn

Hicr idüp odlu sînemi gül-hûn 
$102^{*}{ }^{\text {TAED }} 55$

Mehmet Nuri ÇINARCl

Derd idüp dâglı băgrımı kânûn

Âteş-i 'aşkı gör ki itdi nice

Serv tek kaddimi çü halka-i nûn (6. Bend, 1-3)

Peki, aşığın yüreğine ateş gibi düşen boyunu dala, yüzünü asfere çeviren bu aşk derdinin devası nedir ve hekimi kimdir? Tasavvufi manada sadece sakinamelerde değil divan şiirinde dahi aşk derdinin dermanı şarap yani Allah aşkı, hekimi ise saki yani mürşid-i kâmildir. Sâkînâme'de hastayı iyileştirecek derman ve hekim ile ilgili beyitler şunlardır:

Sâkiyâ ey tabîb-i müştâkân

Meni öldürdi derd-i bî-dermân

Lutf kil eyle derdime çâre

Şeng ü şengâne eyle bir devrân

Başımı istesen urur hancer

Câna şevkün çeker eger bu cân

Muhtasar devr getür şerâb şerâb

Eyle bu derd-i mihneti büryân

Derd-i 'aşkun devâsı meydür mey

Geldi sultan-ı 'aşkdan fermân

Câm-ı gîtî-nümâyı bu zâlim

Matlabun her ne olsa eyler 'ayân (5. Bend, 1-5)

Sâkiyâ bu humâra eyle 'ilâc

Lutf kll birce gel terahhuma sen

Gönlümü tîre kıldı gird-i melâl

Bâde vir it bu şem 'i bir rûş̧en (9. Bend, 18-19)

Sakiden himmet alarak aşk yoluna giren gönül ehlinin nazarında, sadece sevgilinin rızasını kazanmak esastır. Bu yüzden dünyevi olan her şey onun gözünde bir hiçtir. Dünya 
malının varoluş sebebi ise aşığın onu sevgiliye feda etmesidir. Malı feda konusunda bir an bile tereddüte düşen kişi sevgiliye ihanet etmiş olur.

Himmet it geç bu pûç dünyâdan

İtginen cân ü mâll yâra nisâr

Senün olsun cemî'-i mâl-ı cihân

Bana zâhid tamâmdur bir yâr

Yarsiz bir harâbe-i külhen imiş

Sahn-ı bostân ve gûşe-i gülzâr (8. Bend, 20-22)

Sâkiyâ devr-i ayağa mestâne

Geldi sultân-ı gül gülistâne

Katır u at u mâl ü emlâkl

Cümlesin eyle harc-ı mey-hâne (12. Bend, 1-2)

Bütün bu eziyete rağmen âşık, şaraba, sakiye ve meyhaneye bu kadar uzak kaldığı için pişmanlık içerisindedir. Ona göre dünya, geçici olduğu için şimdiye kadar Allah aşkından ayrı geçirmiş olduğu bütün yaşantısı boşa geçmiştir. Dünyanın fani oluşunun en somut örneği ise bir zamanlar haşmetleriyle dünyayı kasıp kavuran Hüsrev, Behram ve Rüstem gibi hükümdarlar ile aşkları dillere destan olan Vamık, Azra ve Şirin gibi aşk ehillerinden en ufak bir kalıntının dahi kalmamasidir.

Devr ki geçdi şebâb-ı ’ömr-i 'azîz

Bâde virmekde kll şitâb şitâb

Senün olsun o bâde-i kevser

Bana zâhid bu sagâr-ı mey-i nâb (3. Bend, 7-8)

Sâkiyâ durma devr getür bâdâ

Gitdi beyhûde ‘ömrümüz bâda

Çün dil-i şâda yâr şevk eyler

Gönlümü menzil it o dil-şâda (4. Bend, 1-2) 
Hani Hüsrev o şâh-ı key-haşmet

Şîdd'e n'oldu hani güzel Behrâm

Hani Vâmık ne geldi 'Azrâ'ya

N'oldu Selmâ o dilber-i hoş-nâm

Hani Şîîn o şâh-ı ma'şukân

N'oldu Şebdîz o hink-i rahşü'l-câm

Hani Rüstem ki heybetinden onun

Dem çekinmezdi bîşede zirgâm

Hani sultân-ı cümle lâle-ruhân

N’oldu Yûsufo şâh-ı mâh-ı gulâm (10. Bend, 4-8)

Bilindiği gibi sâkînâmelerde mey, saki, meyhane, musiki ve tabiat tasvirleri gibi içki meclislerinin çeşitli unsurları hakkında bilgi verilir. Nebâtî, Sâkînâme'sinde bu unsurlardan ilk olarak bahar tasviriyle işe başlar. Baharın gelişiyle ilgili dizelerinde sakiye seslenen Nebâtî, ilkbaharın gelmesiyle birlikte sevgiliye kavuşma anı ve içki içme mevsiminin de eriştiğini söyler. Bahar tasvirinde göze çarpan en belirgin durum ise; lale, gül, nergis, bülbül ve murgzar gibi ifadelerle canlı bir bahar bahçesi tablosunun çizilmesidir. Nisan yağmurları ve gök gürültüsü de tabloyu tamamlayan temel unsurlardandır:

Sâkiyâ geldi nev-bahâr gine

Mevsim-i geşt ü lâlezâr gine

Virginen bezm-i inbisâta şükûh

Geldi hengâm-ı vasl-ı yâr gine

Nergis-i mest-yüz nezâket ile

Zülfini itdi müssk-bâr gine

Şâh-ı gül gütdi burka'ın üzden

Hüsnini itdi âşikâr gine

Kûh u șahrânı ebr-i nisânı 
Gör ne hoş itdi murgzâr gine

Ra'd-i gurrân çeküp gırîv ü hurûş

'Âleme saldı hâr hâr gine

Şâh-ı gül oldı mesken-i bülbül

Lâleni itdi dâğdâr gine

Hardasin ey şeker-leb ü gül-ruh

Vir gözüm câm-ı hoş-güvâr gine (2. Bend, 1-9)

Baharın gönülleri hoş eden ve aynı zamanda ıyş çağının geldiğini müjdeleyen tabiat tasvirinden sonra sakinin özelliklerine geçilir. Nebâtî'nin şiirinde, sakinin hem fiziki vasıflarından hem de kendisi gibi gönül ehillerinin nazarında nasıl algılandığından bahsedilir.

Sâkiyâ ey mebâdî-i âdâb

Ey serâc-ı dil-i ülü'l-elbâb

Ey gül-i gülsitân-ı mahbûb

Ey ruhun şem'-i mahfil-i ahbâb

Târ-ı zülfin kemend-i gerden-i cân

'Ârızın tek hani gül-i şâd-âb

Leblerün la'l ü gabgabin sîmîn

Kâmetin kıble kaşlarun mihrâb

İdesen bu fakîri ger hoş-dil

Bundan artık nedür sevâb sevâb (3. Bend, 1-5)

Sâkînâme'nin birçok yerinde şarap ve mey isimleri de kullanılarak içkiden bahsedilir. Ancak içkinin temel vasıfları ve âşıklar üzerinde nasıl bir tesir bıraktığı ile ilgili 7 ve 9 . bentlerde bilgi verilir. İçkinin vasıflarını sıralayan Nebâtî, genellikle nasıl ve ne sebeple ortaya çıktığını ifade etmekten ziyade tasavvufi bağlamda insanlar üzerindeki tesirinden bahseder. $\mathrm{Bu}$ tesirlerden ilki ölüleri dahi diriltmesi, ikincisi ise aşk derdine deva olmasıdır. Bununla birlikte mecliste içki içildiği zaman edep kurallarına uyulması gerektiği özellikle vurgulanır: 
Hayy ider mürdeni Mesîh kimi

Cân bulur içse kâlıb-ı bî-cân

Zâhide doğru söz menüm mey ü câm

Senin olsun o bâde-i Rıdvân (7. Bend, 6-7)

Sâkiyâ ey nigâr-l şîîin-fenn

Hardadır ol devâ-yı derd-i hüzn

Telh-i şîrîn-güvâr ya'ni mey

Merd olur içse ger onu her zen

Bu idi itdi şâh Cemşîd'i

Hatta câvîd çün Üveys-i Karen

İhtirâm it ki câm-ı Cem'dür bu

Olma bed-mest sen de çün Behmen

Ele aldıkça gözle şart-ı edeb

Ki odur derd-i 'aşka çâre iden

Hani ol gürd şîr-i ner-savlet (9. Bend, 1-6)

Birkaç beyitte ise içkinin renginden söz edilir. $\mathrm{Bu}$ renk genellikle kırmızı olması sebebiyle güle benzetilir.

Mey-i gül-reng vir ki ol ma'cûn

Belki itsün bu asferi ahmer (5. Bend, 6)

Sâkîyâ devr getür mey-i gülgûn

Meni gam itdi lâle tek dil-hûn (6. Bend, 1)

Gelse meydâne bâde-i gül-reng

Bâğda gezmez gurâb bigâne (12. Bend, 10)

İçki meclislerinin olmazsa olmazlarından biri de şüphesiz musiki ve musiki aletleridir. İlahi aşkın terennümü esnasında müzik aletleri de bu coşkuya eşlik ederek aşığın mey eşliğindeki kendinden geçişe ortak olur. Sâkînâme'de tar, kanun, çeng ve rebab gibi müzik 
aletlerinin yanı sıra Müberrik, Nişaburi, Hüseyni ve Zemin-i harâ gibi müzik makamlarından da behsedilir. İçki meclislerinde şarkı söyleyip çalgı çalan mutrib ise sadece bir yerde zikredilir.

Men-i müştâk bu hikâyetde

Geldi nâ-geh nevâ-yı târ gine (2. Bend, 22)

Men ve sâkî harâb bâde iken

Yitdi nâ-geh kulăga bâng-ı rebâb (3. Bend, 16)

Men ve sâkî bu köpde nâ-geh çeng

Çekdi bir nâle geldi feryâda (4. Bend, 25)

Hicr idüp odlu sînemi gül-hûn

Derd idüp dâğlı bağrımı kânûn (6. Bend, 2)

Geh Müberka' gehî Nişâbûrî

Geh Hüseynî gehî Zemîn-hârâ

Tâ salam bu cihâna bir gulgul

Başlayum tâze bir 'acîbe nevâ (1. Bend, 15-16)

Men-i dîvâne bu hikâyetde

Nă̆me-sâz oldı mutrıb-ı hoş-han

Didi ey mutrıb-ı keş-â-keş-i 'aş̧

İstemez çoh da hüccet ü bürhân (7. Bend, 18-19)

İcki meclislerinin diğer önemli iki ziyneti ise mum ve kadehtir. Mum yani diğer ismiyle şem', meclisi aydınlatan ve genellikle saki tarafından meclise getirilen bir bezm unsurudur. Ancak Sâkînâme'de sadece bir yerde kullanılmıştır. Kadeh ise meclis erbabının içkilerini içtikleri ve şiirde cam ya da ayak olarak da adlandırılan diğer bir bezm unsurudur. Sâkînâme'de kadehin umumiyetle rengi ve içkiye kattığı lezzetten bahsedilmiştir:

\author{
Mahfili rûşen it getür şem 'i \\ Âteşi germ kıl kavur bâdâm (10. Bend, 2) \\ Hardasin ey şeker-leb ü gül-ruh
}


Vir gözüm câm-ı hoş-güvâr gine

Gel içah bâde gül ayă̆ında

Bir idah şükr-i Kird-gâr gine (2. Bend,-8-9)

Bana vir bir o câm-ı gülgûni

Gücüni 'akl-ı dûna bir göster (5. Bend, 19)

Câm-l zerrîni devr getür devre

Tâ ideyüm men bu nazmı tamâm (10. Bend, 10)

Sâkînâme'nin hemen hemen tamamında tasavvuf kaideleri gözetilerek Allah aşkıyla Hak yoluna eren ve sakiden bu konuda her daim yardım isteyen bir mürit vardır. İçki meclisine ait bütün unsurların yer verildiği eserde, belirgin bir dinî telkin söz konusu olsa da Nebâtî, Sâkînâme'nin sonuna doğru aslında neyi kastettiğini ve asıl mesajının ne olduğunu açikça ortaya koymaktadır. Osmanlı sahasında yazılan tasavvufi sakinamelerin bir kısmında müellifin içki hakkında verdiği bilgiler onun ya geçmiş yaşantısında ya da içinde bulunduğu ortamdan dolayı içki meclisini tanıdığı fikrini güçlendirmektedir. Ancak Nebâtî’nin şiirinin geneline bakıldığında onun kendini Hak yoluna adayan bir derviş olduğu ve içki ile ilgili unsurlara da bu kaide çerçevesinde yer verdiği çok belirgindir.

Beng ü afyona olma âlūde

Olma bed-nâm bî-ser ü ezlâm

Hamrdan ihtirâz kll olma

Fiska meşhûr sen de çün Hayyâm

Tapasan tâ makâm-ı zühd ü vera'

Hıdmet-ı evliyâya kıl akdâm

Dutginen dâmen-i şerî̀atdan

Eyle hifz-ı merâtib-i İslâm

Zikr ü tesbîhe dâ'im ol meşgûl

Gice gündüz 'ibâdet eyle müdâm

Sâkîyâ kimdür bu dırâz nefes 
Ki meni zâra gütdi bu haccâm (11. Bend, 17-22)

Nebâtî’nin hayatı mevzusunda da ifade edildiği gibi şair, ilk zamanlarında tasavvuf ehli bir derviş iken Nimetullahi tarikatına mensubiyetinden sonra Şii mezhebine dair temayüller göstermiş ve bu ilgi şiirlerine de yansımıştır. Sâkînâme'nin önemli bir kısmında Hazreti Ali’ye duyulan aşırı hayranlık da şairin Şiiliğe karşı olan tavrını ortaya çıkarması bakımından kayda değerdir. Bu hayranlık öyle bir derecededir ki eserin 12. bendinde Hazreti Ali'den meded dilenmesi gerektiği vurgulanır:

Ey dil-i müstmend-i hûn-âşâm

Yüz çevir birce şâh-ı şâhâne

Mîr-i Yesrîb hidîv-i külli ümem

Şîr-i Yezdân 'Alî-i 'Imrâne

Şâh-ı müşkil-güş̄a 'Alî'dü̈r 'Alî

Ki virür nazm çarh-ı gerdâna

İste ondan murâd ü maâlabını

Her nedür korhma merd-i merdâne (12. Bend, 11-14)

11. bentte ise şair Hazreti Ali’ye olan hayranlığını muhabbet sözcüklerine dökmüş ve Şii mezhebince mühim olan sahabelerden Ebulfazl el-Abbas ve Hazreti Ali'nin oğlu Abbas'ın isimlerine de yer verilmiştir:

Ey 'alemdâr-l şâh-ı teşne-ciger

Sana kurban menüm atam anam

Here bir şâhı sevmiş ezelden

Seni sevmiş Nebâtî-i bed-nâm

Geh Ebu'l-fazl gâh yâ 'Abbâs

Diyerem eyledüm sözü itmām (11. Bend, 27-29)

Mutasavvıf şairlerin önemli bir kısmının eserlerinde olduğu gibi Nebâtî’nin divanında da herhangi bir hükümdara yazılmış methiyelere rastlanmaz. Nebâtî’nin yaşadığı tarihlerde 
İran'da hüküm süren hanedanlık Kaçar hanedanlığıdır. Sâkînâme'nin sonlarına doğru Nebâtî'nin devrin hükümdarı Muhammed Şah Kaçar’ı övdüğü birkaç dizeye rastlanır:

Here bir şâha oldular meddâh

Men kimin bende şâh-ı Îrân'a

Şâh Rüstem süvâr-ı Dârâ-fer

Ki düşüp sît-i 'adli devrâne

Şâh gazi emîr-i deryâ dil

Mîr-i bâzil veliyy-i Sübhâne

Şâh bin şâh mefhar-ı Kâçâr

Ki salup diyü zulmı zindâna

Şeh Mehemmed şeh-i Sikender-şân

İltifât itmez âb-ı hayvâna

Her yana yüz çevirse feth ü zafer

Koyalar baş ölünce fermâna

Hâdem-i bârgâha yüz Cemşî̀d

Ta’n ider câhı min Süleymân'a (12. Bend, 17-23)

\section{Sonuç}

Klasik edebiyatımızda sâkînâmeler, XIV. yüzyıldan itibaren başlayarak hemen her yüzyılda örnekler vermiş bir türdür. İlk örneklerinin Anadolu dışındaki Türk edebiyatlarında verildiği sâkînâmeler, Fars edebiyatında ortaya çıkmıştır. Sâkînâmelerde mey, saki, kadeh, musiki ve şem' gibi içki meclislerine özgü çeşitli unsurların yanı sıra içkinin nasıl bulunduğu, içkinin içildiği mevsimlerin tabiat tasvirleri ve bu meclislerde nasıl davranılması gerektiği ile ilgili bilgiler de verilmiştir. Divan edebiyatında kaleme alınan sâkînâmelerde, kimi zaman gerçek bir içki meclisinden bahsedilebildiği gibi kimi zaman da bu meclislerin sadece sembolik birer değer taşıdıkları ve tasavvufi bir hüviyete sahip oldukları görülmektedir. Tasavvufi karakter taşıyan sâkînâmelerde şairler, bezme ait her bir unsura tarikat geleneklerinin gerektirdiği şekilde çeşitli manalar yüklemişlerdir. Buna göre aşk derdine düşen kişi mürit; saki, 
mürşid-i kâmil; mey, Allah aşkı; meyhane ise tekkedir. Osmanlı sahası Türk edebiyatının yanı sıra İran'da teşekkül eden Azeri edebiyatında da Türkçe sâkînâmeler yazılmıştır. Mutasavvıf bir şair olan Seyyid Ebulkâsım Nebâtî de sâkînâmesi olan XIX. yüzyıl Azeri şairlerinden biridir.

Bugün İran topraklarında bulunan Üştübin'de doğan Nebâtî de sâkînâme yazmış şairlerden biridir. Terci-i bend nazım şekliyle yazılmış olan sâkînâme, şairin divanında yer almaktadır. Nebâtî, küçük yaştan itibaren babasından aldığı dinî eğitimle müteddeyyin bir yaşantı sürmüş ve gençliğinin ilk yıllarından itibaren tasavvufa meyletmiştir. Tasavvufi dünya görüşünü benimseyen şair, bunu şiirlerine de yansıtmış ve ağırlıklı olarak insanları Hak yoluna davet eden metinler kaleme almıştır. Nimetullahi tarikatıyla tanışan Nebâtî, Şiiliğe ilgi göstermiş ve bu ilgisi divanındaki şiirlerinde kendini hissettirmiştir. Nebâtî'nin Sâkînâme'sinde de fikri dünyasını bu denli derinden etkilemiş tasavvuf ve Şiiliğin derin izleri görülür. Mutasavvıf bir şair olan Nebâtî'nin Sâkînâme'si belirgin bir şekilde tasavvufi bir nitelik taşır. Nebâtî, içki ve içki meclislerine özgü bütün unsurlara tasavvufi bir mana yükleyerek etrafindaki insanlara tasavvufi kaideleri öğretmeye çalışmıştır. Tasavvufun yanı sıra Sâkînâme'nin birçok yerinde Şiiliğin de etkisiyle Hazreti Ali’ye duyulan hayranlık çok belirgindir. Eserin sonlarına doğru ise devrin İran hükümdarı Muhammed Şah’ı medh eden birkaç beyite yer verilmiştir.

\section{SÂKÎNÂME-İ SEYYİD EBULKÂSIM NEBÂTî}

$-1-$

Ey iden caş̧ nāmesin inşāa

Veh düşüp başın̄a caceb sevdā

Koyginen başa tāc-1 Bismi'llāh

İbtidā ḳ1 sözi be-nām-1 Hูudā

Ki odur her kelāma ser-mațla ${ }^{c}$

Ki odur server-i heme esmā

Kāāir-i züu'l-celāl ve'l-ikrām

Fālaḳu's-suhub ḩāliḳu'l-eşyā

Șānic-i carş u ferş ü şems ü ḳamer

‘Ālemi yohndan eyleyen peydā

Ol Hुudāvend-i vācibü'l-tac'̣̄ìm

Ḥayy u ḳayyūm ve ferd-i bī-hem-tā

Āḥsenü’l-hāllḳ̄in lehü'l-cizzet

Velehu'l-ḥamd ve's-ṣenā-i calā

Ādemi o yaratdı topraġdan

Başına ḳoydı tāc-1 kerremnā

Buldu ondan eserer dem-i ì̃sā

Tapdı ondan șafā yed-i beyżā

Ondan oldu Muhammed-i ${ }^{c}$ Arabī

Șậịib-i tāc ü taḥt idādına 
Ey ḳalem ey enīs-i ehl-i beyān

Cehd k1l itgilen sözi zībā

Gel getür bâde ey gözüm sāḳ̄

Ki vireyüm ${ }^{4}$ çehre-i maḳāla șafā

Şūr u şeh-nāzdan ${ }^{5}$ çekeyüm āheng

Nāleni eyleyüm bülend-āvāz

Șavt-1 Dāvūd'ı eyleyüm zāhīr

Laḥn-1 İdrīs'i eyleyüm inşā

Geh Müberḳac ${ }^{c}$ gehī Nişābūrō

Geh Hüuseynī gehī zemīn-hāāā

Tā salam bu cihāna bir ġulgul

Başlayum tāze bir cacībe nevā

Geleler ${ }^{6}$ vecde cāşı u u cārif

Düşeler raḳṣa pādişāh ü gedā

Evcden başla rāk-1 Nevrūz'1

Çolkasun nüh sipihri șavt ü șadā

Şāh-1 İslām'a rūz u şeb nuṣret

İste Haḳ'dan hemīşe eyle ducāa

Çekgilen başa bāde-i caşḳ̂

Künbed-i çarḩı eyle pür-ġavḡā

Şāh-1 Mıșr'1 çıhartgilen çahdan

cĀlemi eyle vālih ü şeydā

Diginen yā cAlī be-ṣavt-1 celī

Eyleme hiç kimiseden pervā

Himmet al pīrden meded Haḳ'dan

Dem-be-dem hū çeküp yola başla

Koy ḳadem rāh-1 caşḳa merdāne

Gir harābāta mest ü mestāne

$$
\text { -2- }
$$

Sākiyā geldi nev-bahār gine Mevsim-i keşt ${ }^{7}$ ü lālezār gine Virginen bezm-i inbisāṭa şükūh Geldi hengâm-1 vaṣl-1 yār gine Nergis-i mest-yüz nezāket ile

Zülfini itdi müşk-bār gine

Şāh-1 gül gütdi burḳacın üzden

Hüsnini itdi āşikār gine

Kūh u șaḥrānı ebr-i nisānı

Gör ne hoş itdi murḡzār gine

Recd-i gurrān çeküp ġırīv ü huurūş

cĀleme șaldı hāar hāar gine

Şāh̆-1 gül oldı mesken-i bülbül

\footnotetext{
${ }^{4} \mathrm{~B}$ : virem

${ }^{5} \mathrm{~B}$ : şūr-1 şehnāzdan

${ }^{6} \mathrm{~B}$ : geldiler

${ }^{7}$ B: keșt-i
} 
Laleni itdi dāğdār gine

Hardasın $^{8}$ ey şeker-leb ü gül-ruh

Vir gözüm cām-1 hoş-güvār gine

Gel içah bāde gül ayaġında

Bir idah şükr-i Kird-gār gine

Gündü Yārab cihānı rūşen iden

Yā çıhup seyre ol nigār gine

Şaḥn-1 gülzārı itdi bāg̀-1 İrem

Dilber-i şeng-i gül-cizāâr gine

Sāmirī siḥrini ḳılup zāahir

Nergis-i şūh u pür-humāār ${ }^{9}$ gine

Sāḳiyā basdı gönlümü zengār

Aldı āyīnemi gubār gine

Devr getür ol müferrih ruhı

Kes görah bir iki anar gine

Çarh vur ey cikāāb-1 tīz-nazāàr

İt gözüm bir güzel şikār gine

Vurginen şāh-1 lā-fetādan dem

Düşmeni eyle tārümār gine

Ohu lā-seyfe zikrini her dem

Gör nedür berḳ-i Zülfikār gine

Ey șabā ey berīd-i cāşıḳ-1 zār

Kūy-1 cānāne birce var gine

Açginen şāh-bāz tek şeh-per

Eyle şīrāze bir güzār gine

Hāfız’’ın rūḥ-ı pākine bizden

Bir yitür caşk - 1 bī-şümār gine

$\mathrm{Ba}^{\mathrm{c}}$ de el-ḥamd ve sūre-i İḥlās

Gör nedür bir yār-1 gāār gine

Men-i müştāḳ bu hikāyetde

Geldi nā-geh nevā-yı tār gine

Didi ey derd ${ }^{10}$ ü gam giriftārı

Çoh dahi itme āh ü zār gine

Dutginen ${ }^{11}$ dāmen-i tevekkülden

Aşḳar-1 'aşḳa ol süvâr gine

Koy ḳadem rāh-1 caşḳa merdāne

Gir harābata mest ü mestāne

-3-

Sākiyā ey mebādī-i ādāb

Ey serāc-1 dil-i ülü'l-elbāb

Ey gül-i gülsitān-1 maḥbūb

\footnotetext{
${ }^{8}$ B: hardasan

${ }^{9}$ B: gül-cizāār

${ }^{10} \mathrm{~B}$ : derd-i gam

${ }^{11} \mathrm{~B}$ : dutgilen
} 
Ey ruhuun şemc-i maḥfil-i aḥbāb

Tār-1 zülfin kemend-i gerden-i cān

cĀrıżın tek hani gül-i şād-āb

Leblerün lacl ü gabgabīn sīmīn

Kāametin ḳıble ḳaşlarun̄ miḥrāb

İdesen bu faḳīi ger hoş-dil

Bundan artıḳ nedür sevāb sevāb

Geçmez cārif bu neşeden Bi'llāh

Ṭarf-1 cū pāy-1 gül şeb-i meh-tāb

Devr ki geçdi şebāb-1 ${ }^{\mathrm{c}}$ ömr-i ${ }^{\mathrm{c} a z \bar{z}}$

Bāde virmekde ḳıl şitāb şitāb

Senün̄ olsun o bāde-i kevser

Ban̄a zāhid bu sag̣ār-1 mey-i nāb

Cezbe-i zevk-i sohbet-i yārān

Diyesin saldı cānıma küullāb

Sākiyā ey hümā-yı zerrīn-bāl

Bu ne Tebrīz'dür bu ne șürḥ-āb

Ban̄a bir cām-ı bāde-i aḥmer

Kerem it ey kirāmü'l-elkāa

Müjde ey cākifān-1 ḳacbe-i caşk

Şāhid-i müdde ${ }^{1}$ götürdü niḳāb

Neş ${ }^{\circ}$ başımda mey ayağımda

Ne ümīd nicm ne bīm-i cazāāb

Mațlabım ḥāṣıl itdi şāh-1 bütan

Kāmımı virdi ol büt-i Süḳlāb

Şükri'llāh ki kevkeb-i bahtım

Oldı rahşān çü mihr-i cālem-tāb

Men ü sākī harāb bāde iken

Yitdi nāgah ḳulag̉a bāng-1 rebāb

Didi ey mest-i sāgāār-1 cişret

Dur uyan itme çoh da şükr-i hāāb

Pīr-i meyhāneden gel al himmet

Diginen yā müfettihe'l-ebvāb

Koy ḳadem rāh-1 caşḳa merdāne

Gir harābata mest ü mestāne

\section{$-4-$}

Sāḳiyā durma devr getir bāda

Gitdi beyhūde cömrümüz bāda

Çün dil-i şāda yār şevk eyler

Gön̄lümü menzil it o dil-şāda

Ne beyān-1 meliḥ ilen bilmem

Getürim men bu naḳli īrāda

Hani bir nev-cevān-1 cāşıḳ-veş

Hani bir rind-i mest-āzāde

Ola esrār-1 caşḳdan vāḳıf

Böyle bir kim ne var bu gavgāda 
Meni yandırdı bir melek-manz̧ar

Meni öldürdü bir peri-zāda

Aldı șabr ü ḳarārımı elden

Meni āḩir getürdi feryāda

Döndü bir bī-vefādan ötürü hāy

Gözümün yaşı şațț-1 Bag̉dād'a

Meni öldürme ey ecel bir dem

Koy biraz yalvarim o cellāda

Rencsiz rāḥat olmaz ey og̉lan

Yüri git kulluk eyle üstāda

Ķurmamış dām çekmemiş zaḥmet

Kim virür şāh-bāzı șeyyāda

Ey ḩıāmān gezen çemenlerde

Göz tegin nahll-1 serv-i şimşāda

Çölde yākut u lacl u mervārid

Būy-1 İslām ve deyr-i tersāda

Çeşme vü cūda gevher ahtarma

Yüri gavvāṣ̣ı gözle deryāda

Körgeç abdālı öp ayaġından

Cān fedā eyle ḳavm-ı evtāda

Kuluyum men ḳalenderün ḳuluyum

Yã cAlī sen yetişginen dāda

Ey dirīgāā ki geçdi mevsim-i gül

Gözümüz ḳaldı cām-ı șaḥbāda

Olsa her yerde cennet orda imiş

Bāde-i șāf ve sâkī-i sāde

Mümkün oldukç̧a ${ }^{c}$ 1yş u cişret ḳ̂l

Furșatı șalma rūz-1 mī̄āda

Özin̄i salma kayd-1 taḳlīde

Boyn̄una tahma tavḳ-1 küllāde

Eyleme her gedā ilen ülfet

Darb-1 teşnīe olma āmāde

N'oldu dağlarda seyr iden Mecnūn

Üregim yandı renc-i Ferhād'a

Sāḳi cān gözle ahd ü peymānı

Hayfdur virme bāde her yāda

Nā-necībin bināsı yohdur yoh

Olsa ger başı carş-1 aclāda

Men ve sākī bu köpde nā-geh çeng

Çekdi bir nāle geldi feryāda

Didi ey mübtelā-yı şūr-1 cünūn

Ne batupsan bu naẓm-1 efrāda

Koy ḳadem rāh-1 caşḳa merdāne

Gir harābāta mest ü mestāne

$-5-$

Sākiyā ey enīs-i cān-perver 
Meni gam itdi caciz ü muẓtarr

Men ${ }^{12}$ gören zulmi görmesin tersā

Men ${ }^{13}$ çeken derdi çekmesün kāfir

Ne tegāfüldü bu hani mīnā

Ne tacallüldü bu getür sāgar

Vir pey-ā-pey o ḳana dönmüşden

Üregüm yandı dutmuşam āzer

Derd idüp serv-i ḳaddimi çün dāl

Hicr idüp reng-i ālımı aṣfer

Mey-i gül-reng vir ki ol maccūn

Belki itsün bu aṣferi aḥmer

Ey ḳalem ey hüceste-i nuț u maḳāl

Vah ki itdün sözü gine şekker

Haḳ bilür yohdu böyle meşşāte

Ki vire min carūṣa bu zîver

Pīç ü tāb itme hardasın heyhāt

Salginen baḥr-1 caşḳa bir lenker

Devre gel sāḳiyā getür cāmı

Himmet it birce söyle yā Haydar

İtginen cām-1 'aşḳı māl-ā-māl

Eyle bu nahll-1 huşkı bir aḩżar

Şükr șad şükr geçdi şām-1 firāḳ

Şecer-i hicr yahşi gitdi șemer

Men ve min bacd sāḳ̄i vü mey ü cām

Men ve min bacd dāmen-i dilber

Şükr-i eyyām-ı vaṣl ḳıl ey dil

N'oldu ol gün ki dirdün inne mefer

Hardadır sākī ol sefīne-i Nūḥ

Ki idem bir feżā-yı çarḩa sefer

Ḳıl meni bir ḩarāb-1 cām-1 şarāb

Salgilen bir bu cism ü cāna şerer

Kaṣr-1 Firdevs yitdü zāhid içün

Men ve pīr-i mugāān ve ehl-i saḡār

İtdi sākī neheng-i küfr-i țulū ${ }^{c}$

Düşdi deryā-yı caşḳa mevc-i hațar

Ban̄a vir bir o cām-1 gülgūni

Gücün̄i caḳl-1 dūna bir göster

Hardasın bir es ey nesīm-i murād

Yārdan bu faḳīe birce haber

Ey dil-i nā-tüvān ü zār ü ḥaz̄nn

Kim seni böyle eyleyüp münter

Ohu nād-1 ${ }^{\mathrm{c} A}$ līni şām u șabāḥ

Eyle bu ism-i $a^{c} z m i$ ezber

${ }^{12} \mathrm{~B}$ : ben

${ }^{13} \mathrm{~B}$ : ben 
Koy ḳadem rāh-1 caşḳa merdāne

Gir harābāta mest ü mestāne

-6 -

Sākiyā devr getür mey-i gülgūn Meni gaam itdi lāle tek dil-ḩūn Hicr idüp odlu sīnemi gül-hū̄n Derd idüp dāğlı bağrımı kānūn Āteş-i caşḳı gör ki ${ }^{14}$ itdi nice Serv tek ḳaddimi çü ḥalḳa-i nūn Sāḳīyā sen mey-i mürevvaḳ vir Men salam yāda bir caceb mażmūn 'Aḳl u maḳl u kemālden geçdüh Gel biraz da dutah țarīke-i cünun Yandırah raḥt u puhtı mestāne ${ }^{15}$ Seyr idaḩ kūçelerde çün Mecnūn Geh idah rakṣ ve gāh ${ }^{16}$ çarh vurah Geh çekah nāle mest ve diger gün Geh diyah şicr ü micr ve geh hezeyān Gāh mest-i şarāb ve geh afyon Gāh ${ }^{17}$ vahşsiler ile hem-cevelān Gāh ${ }^{18}$ ṣaḥrā gezah gehī hāmūn Gāh hayret ${ }^{19}$ çölünde ser-gerdān Dīde-giryān ve hăațarı maḥzūn Gāh dağlarda vālih ü şeydā Gāh aṣ̣āāb-1 Kehf-i garfulun Gāh ${ }^{20}$ ḩāmūş ve geh sahn-güster Gāh efsāne ve gehī efsūn Gelse takrīre ger hikāyet-i caşk Ulu bir demde min gedā Kārūn Ey üzi berg-i gül sözi şeker Devr getir mey ki ec-cünūn-ı fünūn Ey hoş-ā-h̆oş o cāşık-1 kallāş

Ki ide cānı yârine kurban Bāde-i huum-niş̄ini vir sāḳ̂̄ Ne diyer bir görek o Eflāțūn Gāh hem-dest-i lūtyān-1 ḳaşeng Geh zerengī diyah gehī mercūn Geh içāh bāde gāh beng çekah Gāh būtī vurah gehī maccūn

\footnotetext{
${ }^{14} \mathrm{~B}$ : ne

${ }^{15} \mathrm{~B}$ : merdāne

${ }^{16} \mathrm{~B}$ : gehī

${ }^{17} \mathrm{~B}$ : gāhi

${ }^{18}$ B: gāhi

${ }^{19} \mathrm{~B}$ : hasret

${ }^{20} \mathrm{~B}$ : gāhi
} 
Üştübīn eyleyüp meni Tātī

Şicrimi yahşsı eyleyüp mevzūn

Biri '⿳亠̄berī dir biri 'Arabī

Māyil oldum zebān-1 Tātīyemun

cĀşskạam bir nigār-1 Tātīye men

Ki ider siḥr-i Nahş̧ebī ḩayrūn

Meni aldatdı çeşm-i cellādı

Nice bī-çāre Ādemī Şeyțūn

Ǵamzesi yağı cişvesi sāḳ̂̄

Gözleri mest lebleri mey-gūn

Sāḳiyā bah bir ol şehinşāha

Katdı şāhı Āyaza cabd-ı zebūn

Durginen bu kalender-i meste

Virginen bir piyāle-i meşḥūn

Ki diyem bir de elde peymāne

$\mathrm{Na}^{\mathrm{c}}$ ra-zen seyl-i eşki çün Ceyhūn

Koy ḳadem rāh-1 caşḳa merdāne

Gir harābāta mest ü mestāne

-7 -

Sāḳīyā ey țabīb-i müştāḳān

Meni öldürdi derd-i bī-dermān

Luṭf ḳıl eyle derdime çare

Şeng ü şengāne eyle bir devrān

Başımı istesen urur hancer

Cāna şevkün çeker eger bu cān

Muhtașar devr getür şerāb şerāb

Eyle bu derd-i miḥneti büryān

Derd-i caşḳun devāsı meydür mey

Geldi sulțan-1 caşḳdan fermān

Cām-1 gītī-nümāyı bu zāalim

Mațlabun her ne olsa eyler cayān

Ḥayy ider mürdeni Mesīh kimi

Cān bulur içse kāālı-ı bī-cān

Zāhide doğru söz menim mey ü cām

Senin̄ olsun o bāde-i Rıdvān

Merḥabā āferīn ducāa-yı seḥer

Tapmışım sende gör ne künc-i revān

Çıhdı ahter-i muhāạ hạayretden

Gün kimi ${ }^{21}$ oldu țālic ü rahşsān

Luṭf-1 Huak şāmil oldı ḥālimize

Oldı ser-beste ġonçemiz handān

Nahll-ı ümmīd oldı bār-āver

Oldı düşmen ḩadeng-i reşke nişān

Āh-1 dil-sūz yahşi geldi vice

${ }^{21} \mathrm{~B}$ : gün-be-gün 
Çāre-sāz oldu ḳudret-i Yezdān

Gül kenārımda bāde başımda Menzilüm bāg ve hādimüm cānān

Yā cAlī el menüm senün etegün̄

Sen yetiş dāda yā şeh-i merdān

$\mathrm{Ne}$ olur bir görem o gül üzün̄i

Dolanam başına olam ḳurban

Men-i dervīş-i bī-nevā çohddan

Olmuşam nāzlu adına ${ }^{22}$ ḥayrān

Her kimin olsa sen kimi şāhı

Eylemez muṭlāḳa hayāāl-i cinān

Şu'lever oldı āteş-i caşḳum

Üregüm yandı hani ol ${ }^{23}$ ḳalyān

Men-i dīvāne bu hịikāyetde

Nag̉me-sāz oldı muțrıb-1 hosoş-h̆vān

Didi ey muțrrb-1 keş-ā-keş-i caşk

İstemez çoh da hüucet ü bürhān

Koy kadem rāh-1 caşḳa merdāne

Gir harābāta mest ü mestāne

\section{-8 -}

Sākiyā sensiz olmuşum bīmār

$\mathrm{Ne}$ enīsim ne ġam-güsārım var

Üzülüp șabr u ihtiyār elden

Tükenüp cismden ḳarār ü medār

Azalup zevev ü şevḳ ü tāb ü tevān

Çohalup derd ü miḥnet ü tīmār

Devr dönüm başın̄a getür bāde

İtme te’hīr geçdi fașl-1 bahār

Eyle bir cām ilen meni ${ }^{24}$ ser-mest

Ķ1l meni rahşs-1 tünd caşḳa süvār

Tā ideyüm dürr-i naẓmı lacl-i ḩoş-āb

Şirr-i mevzūnı gevher-i şehvār

Sațh-1 eflāke bir çalim şeh-per

Çarh̆-1 hadrāya bir olim devvār

Devr-tā-devr devr-i dünyānı

Bir gezem mişl-i şāḩe-i pür-kār

Getürim Bī-sütūna Ferhād'1

Eyleyüm dag çapanı şīīn kār

Yandırim nār-1 reşke Pervīz'i

Od salam cānına bi-sān-i çınar

Gönderim İșfahān'a Şāpūr'u

Şekkeri yāra eyleyüm ag̉yār

\footnotetext{
${ }^{22}$ B: boyun̄a

${ }^{23}$ B: o

${ }^{24} \mathrm{~B}$ : beni
} 
Āferīn kilk-i siḥr-i perdāzum

Başlayup gör ne hoş güzel hencār

Görginen bir bu Şuşterī-zāde

Ne şīrīn söz diyer şükr-i Girdār

Naķş-1 erjengi eyledi bāṭ̂l

Oldı tā şāh-1 caşḳa nāme-nigār

Reşkden oldı Mānī-i naḳāaş̧

Cism-i bī-cān ve șūret-i dīvār

Sāḳiyā vir piyāle pey-der-pey

Meni yandırdı ol büt-i hūn-hȳār

İderüm tā ḥadīṣ-i caşka şürū ${ }^{c}$

Lāle tek bağrımı ḳalem dagilar

Ey dil-i derdmend-i bī-çāre

Ne içün ḳalmasan böyle nāçār

Devr getür bādā cām-1 Cemşīd'dür

Tökginen cāma bāde-i gül-nār

Himmet it geç bu pūç dünyādan

İtginen cān ü māll yāra nișār

Senün̄ olsun cemī̄ ${ }^{-1}$ māl-1 cihān

Ban̄a zāhid tamāmdur bir yār

Yarsız bir harābe-i külhnen imiş

Şaḥn-1 bostān ve gūşe-i gülzār

Men ve sāḳ̄ ve baḥs-1 zāhidün̄

Geldi nā-geh nevāya musikāar

Didi ey mest-i gamze-i cadū

Bir sözi çoh da eyleme tekrār

Koy ḳadem rāh-1 caşḳa merdāne

Gir harābāta mest ü mestāne

-9 -

Sāḳiyā ey nigār-1 şīrīn-fenn

Hardadır ol devā-yı derd-i hüzn

Telh̆-i şīīn-güvār yacni mey

Merd olur içse ger onu her zen

Bu idi itdi şāh Cemşīd'i

Ḥatta cāvīd çün Üveys-i ḳarn

İhtirām it ki cām-1 Cem'dür bu

Olma bed-mest sen de çün Behmen

Ele aldıķ̧̧a gözle şarț-1 edeb

Ki odur derd-i aaşḳa çāre iden

Hani ol gürd şîr-i ner-șavlet

N'oldu İsfendiyār-i rūyīn-ten

Meni yandırdı bir büt-i ser-mest

Vaṣf-1 hüsni meni idüp elken

Țāḳ-1 ebrū kemānı Sām-1 delīr

Tīr-i müjgânı hançer-i muccen

Ġonçe aġzı çü piste-i ḩandān 
Lebb-i lacli caḳiḳ-i șurḩ-1 Yemen

Ṭarf-1 ruhsārı ravżatü'l-Firdevs

Sünbül-i zülfi reşk-i müşk-i Hुoten

Hูâl-1 ser-sebzi dām-1 fitne vü şer

Çeşm-i ser-mesti kān-1 siḥr ü fiten

Sözi şehd-i şeker gözi şehlā

Cān ü dil bend-i dān-1 çāh̆-1 zekekan

Ḳıya bahmağı rem imiş cīrān

Gül-i cārıż-misāāl berg-i semen

¿İşvesi şūhn gaamzesi cellād

Kan içen hem-çü żayġam-1 ercen

Tīg̀-i bīni yazıldı lā-Yūsuf

$\mathrm{Ca}^{\mathrm{c}} \mathrm{d}-\mathrm{i}$ merḡūlı murg̀-1 cāna vațan

Șūretinden ḥacl meh-i enver

Kad ü bālā bi-sān-i serv-i çemen

Ḳoymaz cāşıł̣da nāzı tāb ü tevān

Öldürür gerçi olsa Ehrīmen

Sāḳiyā bu humāra eyle cilāc

Luṭf ḳıl birce gel teraḥhuma sen

Gön̄lümü tīre ḳıldı gird-i melāl

Bāde vir it bu şemci bir rūşen

Allah Allah kemāl ü kadr ü celāl

Görginen bir o ḳadar zulmün̄

Bu züülūm-1 cühūl-1 insānı

Nice halḳ eyleyüp be-vech-i hüsn

Lafẓ u güftārı gevher-i manẓūm

Ṭarz u reftārı cümle müstạ̣sen

Zāhiri nașṣ-1 ạ̣senü’'l-taḳvīm

Bāṭını sırr-1 vaḥdete maḥzen

Sāḳiyā ḩayl-i gam getürdi hücum

Hardadır ol şarāb-1 mürd-efken

Ey șabā ger töhmetini göresen

Düş ayaġına carż ḳıl menden ${ }^{25}$

Gel o pīr-i mug̉āna yalvaralım

Naz̧ar itsün meger o şāh-1 zemīn

Men ve sāḳī neşāța germ-i țarab

Geldi nā-geh nevāya mey birden

Dedi ey rind-i mest-i şāhbāz

Ne tegafüldü bu devr ey gevden

Koy ḳadem rāh-1 caşḳa merdāne

Gir harābāta mest ü mestāne

-10-

Sāḳiyā ey Sikender-i Cem-cām

Virginen bezm-i ${ }^{1}$ lyşa bir encām

${ }^{25} \mathrm{~B}$ : benden 
Maḥfili rūşen it getür şemci

Āteşi germ ḳıl ḳavur bādām

Gel götür bülbülü getir şūra

Tökginen cāma bāde-i gül-fām

Hani Hüsrev o şāh-1 key-ḥaşmet

Şīdd'e n'oldu hani güzel Behrām

Hani Vāmık ne geldi 'Ažrā’ya

N'oldu Selmā o dilber-i ḩoş-nām

Hani Şīrīn o şāh-1 macşukāan

N'oldu Şebdīz o hink-i rahşü'l-cām

Hani Rüstem ki heybetinden onun

Dem çekinmezdi bīşede żirgāam

Hani sulțān-1 cümle lāle-ruhān

N'oldu Yūsuf o şāh-1 māh-1 gulām

Sākiyā ey gül-i hemīşe bahār

Hardası $^{26}$ olmasun meger sersām

Cām-1 zerrīni devr getür devre

Tā ideyüm men bu naẓmı tamām

Mey getür mey ki çarh-1 kec-reftār

Çohbları eyleyüp böyle nā-kām

Hani şīr-i Hुudā şeh-merdān

Șāhib-i Ž̈̈'l-fikār-1 ḩūn-āşāam

Ger mürekkeb ola cemī̄-i bihāar

Cümle eşcār ola ger eḳlām

Ola kātib-i tamām halḳ-1 cihān

Yazalar vașf-1 şe`nīni mādām

'Āḳibet garkẹ-1 lücce-i haclet

Māt ü mahbūt-1 kāạșru'l-vehhām

Kul kefā Ḥaḳ diyende bir şāha

Men ne tacrīf idüm menüm aḳam

Devr getür bāde sāḳīyā vir cām

Levhaşā'llāh gelün idah bayram

Çekilah bāga bir ayak çekah

Düşah gül ayaġına hoş-kām

Vecd idah menzile virah ziynet

Rūz u şeb cysşa eyleyah aḳdām

N'oldu şemmāme-i firişte-liḳā

Şehr-i Zūr n'oldu hani ol aṣnām

Hani Efrāsiyāb-1 pür-nīreng

N'oldu Șalṣāl o kebir dīv-endām

Gözle ḥayrü'l-kelām şīvesini

Bu sözü eyle şicre şāh-1 kelām

Ol biri cümle-i calāyıkdan

Ṣıdḳ ile baǵlasın da bir iḥrām

\footnotetext{
${ }^{26} \mathrm{~B}$ : hardasan
} 
Koy ḳadem rāh-1 caşḳa merdāne

Gir harābāta mest ü mestāne

-11-

Sāḳiyā mīmi mīme ḳıl idg̣ām

Yen̄iden naẓma vir bir özge nizāam

Bu sözi eyle ziynetü'l-'cuşşāk

Yitdi menşe ${ }^{\jmath}-i$ caşḳdan peygāām

Hardadur sāḳi ol öz-i gülgūn

Raḥmetü’r-rūhn ḳuvvetü'l-ecsām

Șāf ü pākīze çün ciżār-1 bütan

Daficü'l-ḥavf māni'ü'l-ig̀mām

Sırrı gör bī-ḥazīne vü külḩen

Ḳızdırur ḳışda cānı çün hammām

Yūsuf-1 Mıṣr tek 'azīz-i cihān

Min Züleyhāa ona kemīn haddām

Ona çāḳer hezār rāhib-i deyr

Bendesi min cübeyd elf gulām

Vaṣf-1 meyden murādımız sāḳ̄i

Ne imiş ey mübārek aḳdām

Devr getür mey ki yandı şemci mugāan

Gün üzin tīre ḳıldı perde-i şām

Devre gel eyle raḳs hạaleti kerem

Çarh ur bāde vir gidüp nammām

Zülf-i müşkini ḳıl öze efşān

Leyletü'l-ḳadrı eyle bir şemmām

Şerbet-i bīd-i müşke mā'ül-verd

Dāḩil it bir mucațtar eyle meşāmm

Biz muġannī vü muțrib istemenüh

Bir gaazel başla ḩvāceden vir cām

Künc-i halvet hani ki kesdi gine

Erre tek cānımı bu sīn-i selām

Şükrden gāâil olma ey dervīş

Șabr ḳ̂l tā ki ḳādir-i callām

Eylesün cümle müşkili ḥall

Olasan mīr-i a'ç̣imü'l-cazẓām

Beng ü afyona olma ālūde

Olma bed-nām bī-ser ü ezlām

Hamrdan iḥtirāz ḳıl olma

Fısḳa meşhūr sen de çün Ḩayyām

Tapasan tā maḳām-1 zühd ü verac

Hudmet-1 evliyāya ḳıl aḳdām

Dutginen dāmen-i şerī̄atdan

Eyle ḥıfẓ-1 merātib-i İslām

Zikr ü tesbīhe dā'im ol meşgūl

Gice gündüz cibādet eyle müdām

Sākiyā kimdür bu dırāz nefes 
Ki meni zāra gütdi bu hạaccām Tābı yoh menteşāya bu köpgün Harda kalmış menüm o egri 'ișām Durginen sāl bu eşşegi işin̄e Öyle bil kim ki gitdi māh-1 ṣıyām Men hara șoḥbet-i namāz hara Meni azdırdı bu mușāhib-i ham Defter-i caşk ve bāb-1 șavm ü șalāt Mübḥiṣ-i hāa ü hat rüḳuc u ḳıām Ey cālemdār-1 şāh-1 teşne-ciger San̄a kurban menüm atam anam Here bir şāhı sevmiş ezelden Seni sevmiş Nebātīi-i bed-nām Geh Ebu'l-fażl gāh yā cAbbās Diyerem eyledüm sözü itmām Sāḳi vü cām ü şāhid ü gül ü mül Bu idi ve's-selām ve'l-ikrām Gel gözüm dut naz̧arda ol şāhı Muhtașar eyle itme çoḩ ibrām Ḳoy ḳadem rāh-1 caşḳa merdāne Gir harābāta mest ü mestāne

$$
\text { -12- }
$$

Sāḳiyā devr-i ayag̉a mestāne Geldi sulțān-1 gül gülistāne Kaț̣r ve at ve māl ve emlāḳı Cümlesin eyle harc-1 mey-h̆āne Bāde $\operatorname{vir}^{27}$ ḳl lginen $^{28}$ meni ser-germ Ki diyem bir garībe efsāne Eyleyüm Mıṣr'a Yūsuf'1 sulțān Aparim müjde pīr-i Ken`ān'a Şād idüm bir nefes Züleyhā’’nı Getürim rahşs-1 aaşḳı cevelāne Ṭūr-1 Selmān'ı eyleyüm zinde Getürim cism-i mürdeni cāna Sāḳiyā sākiyā dönim başına Gitdi elden bu rind-i dīvāne Devr getür devr getür şarāb şarāb Meni bunca ${ }^{29}$ getürme efğāne Gön̄lümün kişverin kelāl ü melāl İster itsün harāb ü vīrāne Gelse meydāne bāde-i gül-reng Bāg̀da gezmez gurāb bīgāne

\footnotetext{
${ }^{27} \mathrm{~B}$ : virginen

${ }^{28}$ B: k.1

${ }^{29} \mathrm{~B}$ : munca
} 
Ey dil-i müstmend-i hūn-āşāam

Yüz çevir birce şāh-1 şāhāne

Mīr-i Yeșrīb ḥidīv-i külli ümem

Şīr-i Yezdān cAlī-i cİmrāne

Şāh-1 müşkil-güşā cAlī'dür 'Alī

Ki virür naẓm çarh̆-1 gerdāna

İste ondan murād ü mațlabını

Her nedür ḳorhma merd-i merdāne

Ki odur menbac ${ }^{c}$-1 Sühā vü Kerem

$\mathrm{O}$ virüp tāc hā̄n ü hakana

$O$ virüp āfitāba nūr-1 dirahş

$O$ virüp reng-i lacl-1 rahşāna

Nükte-sencān ü şacirān-1 selef

Gütdiler rahşş-1 țab ${ }^{c} 1$ meydāna

Here bir şāha oldular meddāh

Men kimin bende şāh-1 İrān'a

Şāh Rüstem süvār-1 Dārā-fer

Ki düşüp șīt-i cadli devrāne

Şāh ġazi emīr-i deryā dil

Mīr-i bāżil veliyy-i Sübḥāne

Şāh bin şāh mefhar-1 Kaāçār

Ki salup diyü zulmı zindāna

Şeh Meḥemmed şeh-i Sikender-şān

İltifăt itmez āb-1 hayvāna

Her yan̄a yüz çevirse fetḥ ü z̧afer

Koyalar baş ölünce fermāna

Hูādem-i bārgâha yüz Cemşīd

Ṭacn ider cāhı min Süleymān'a

Bahş ider mūra mülk-i dünyānı

Dür töker künc-i luțfi her yāna

Dostu bilmesün ki gam ne imiş

Düşmeni aḳınsun ḳızıl ḳana

Sen Nebātî du'ānı eyle tamām

Ne işün var işitdi şāh yāne

Şükr șad şükr tapdı söz encām

Derdimiz yahşı yitdi dermāne

Kām-1 dil ḥāṣıl oldı müşkil ḥāll

Geldi sāḳ̄ elinde peymāne

Men-i miskīne virdi bir niçe cām

Gitdi hūşum gülāte seyrāne

Geldi nā-geh huurāşa nāle-i def

Bu sözi söyledi șarīhāne

Didi ey mest-i cām bāde-i nāb

Devr dahi besdi Türk-i Türkāne

Kooy ḳadem rāh-1 caşḳa merdāne

Gir harābāta mest ü mestāne 
$126^{*}{ }^{\text {TAED }} 55$

Mehmet Nuri ÇINARCl

\section{Kaynaklar}

Arslan, M. (2003). Aynî, sâkînâme. İstanbul: Kitabevi Yayınları.

Canım, R. (1998). Türk edebiyatında sâkînâmeler ve işretnâme. Ankara: Akçağ Yayınları.

Devletabadi, A. (1355). Sühanverân-ı Âzerbaycan, C. 1. Tebriz: Müessese-i Tarih ve Ferhengi.

Deyhim, M. (1986). Tezkire-i şu'arâ-yı Âzerbaycan târîh-i Zindegî vü Âsâr, C. 1. Tebriz.

Ebulfezl, H. (2004). Nebâtî, seçilmiş eserleri. Bakü: Şark-Garb Yayınları.

Karaismailoğlu, A. (2013). Fars edebiyatında sâkînâmeler. Türkiye Diyanet Vakfi İslam Ansiklopedisi, C. 36. İstanbul: Türkiye Diyanet Vakfı Yayınları, 14-15.

Kortantamer, T. (1983). Sâkînâmelerin ortaya çıkışı ve gelişimine genel bir bakış. Türk Dili ve Edebiyatı Araştırmaları Dergisi II (Prof.Dr. Harun Tolasa Özel Sayısı), 117-123.

Köçerli, F. B. (1920). Azerbaycan edebiyatı tarihi. C. 1. Bakü: Azer Neşr.

Levent, A. S. (1965). Ali Şîr Nevâi, divanlar. C. 2. Ankara: Türk Tarih Kurumu Yayınları.

Sadık, M. H. (1385). Dîvân-ı Eş'âr-ı Türkî, Hakîm Seyyid Ebu'lkasım Nebâtî. Tebriz: Neşr-i Ahter.

Seyyid Ebulkasım Nebâtî, Dîvân - Nebâtî. Bakü El Yazmaları Enstitüsü No: B-651/11152.

Seyyid Ebulkasım Nebâtî, Dîvân-ı Nebâtî (Türkî). Kütüphane-i Meclis-i Şura-yı İslam. No: 1133.

Tebrizi, M. T. M. (1347). Reyhânetü'l-Edeb Fi Terâcimi'l-Ma'rûfin Bi'l-Künye Evi'l-Lakâb: Künâ ve Elkâb, C. 6. Tebriz: Çaphane-i Şafak.

Terbiyet, M. A. (1390). Dânişmendân-ı Âzerbâycân. Tebriz: Neşr-i Ahter. 